\title{
Contemporary English Judges *
}

TN VIEW of the fact that nine-tenths of the discussions in this country 1 of proposals for change in the method of selecting judges have something to say about what is done in England, it appears to be worth while to set out, in this place, a fairly complete description of the present English practice. ${ }^{1}$

With a view to summing up the essential qualities of the government of England as compared with that of the United States, Harold Laski has said:

"The presence of an efficient and neutral civil service, the definite supremacy of the legislature over the judiciary, the allocation of a clear and measurable responsibility to the executive power, a system of local government largely free from the taint of business corruption, party organization which reflects the total economic interests of the commumity, a method of discovering leadership, especially in the national field, which is something more than a lottery, these, I believe, are the main reasons for whatever success our system has had."2

Differences in the structure and operation of the two systems of government, like those suggested by the passage just quoted, must obviously be taken account of in the search for significant comparisons and contrasts between the English judicial system and our own.

At the outset, it is necessary to recall very briefly the names and nature of the principal Enghish courts. ${ }^{3}$ At the bottom of the hierarchy of civil courts are the County Courts, one in each of fifty-five circuits, corresponding roughly to counties. In some of the urban circuits the court sits in a single place; in some of the rural circuits it is itinerant. There are now, I believe, fifty-six County Court Judges; and their salaries are $£ 2,000$ per year, having recently been raised from $£ 1,500$. They hear cases involving up to $£ 100$, a great variety of types, jurisdiction of which has been given by statute from time to time. ${ }^{4}$

*This paper is to be a chapter in a book to appear soon, dealing with the selection and tenure of judges.

1 There are several excellent discussions of the present-day English courts and judges, notably one by Mr. R. C. K. ENsor, CourTs \& Judges IN FranCE, GerMaNY and ENGLAND (1933). Another is a remarkable essay by HAROLd LASKI, THE TEcH-

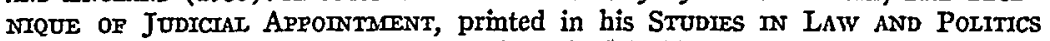
(1932). I must mention also a delightful book by Mr. Theobatd Mathew, Fon LawYERS AND OTHERS (1937), which is no less illumimating for being in the form of a series of disconnected, lightly written, and quite irreverent essays.

2 Foreword to D. W. Brogan, Governament of the People (1933).

3 For a detailed description of the English system of courts, see the articles on Courts and on County Courts (and related articles) in HaLsBury's Laws of ENGland (1933). And see C. P. Patterson, The Adainistration of Justice in Great BRITARN (1936).

4 Notably Workmen's Compensation cases. There is a good deal of agitation for raising the upper himit of the courts' ordinary jurisdiction; but the Bar appears not to approve. 
The position of County Court Judge is one of considerable dignity, the salary is substantial, and an adequate retirement system exists; and it is said, with an occasional rather mild dissent, that the level of ability among this group of judges is very high. ${ }^{5}$

Next above the County Courts comes the High Court, in three Divisions. It is the principal court of first instance; the court which is generally in mind when the Enghish courts and judges are spoken of in this country. The King's Bench Division, made up of the Lord Chief Justice (salary $£ 8,000$ ) and not more than nineteen puisne judges $£ 5,000$ each), is the principal criminal court for the country, and also the civil court for all actions beyond the jurisdiction of the County Courts which do not fall to the other two Divisions of the High Court. The Chancery Division consists of the Lord Chancellor (who seldom sits, in recent times) and six puisne judges; the Probate, Divorce and Admiralty Division, of the President of that Division (salary, like that of the puisne judges, $£ 5,000$ ), and two puisnes. The judges of the High Court sit singly. The judges of the King's Bench Division spend part of their time travelling about the country on Assize (holding court in some places that liave ceased to be very important, and ignoring others that have become very much so), but the other Divisions of the court sit only in London, where most of the country's judicial business is done, including the bulk of that executed by the King's Bench.

Next comes the Court of Appeal, which normally sits as two courts of three judges each, (although as many as thirteen have sat in a single case), and hears appeals from the High Court and the County Courts. It consists regularly of the Master of the Rolls $(£ 6,000)$, and five Lords Justices of Appeal ( $£ 5,000$ each); and potentially of several ex officio members in addition, namely, (besides the Master of the Rolls), the Lord Chancellor, the Lord Chief Justice, the President of the Probate, Divorce and Admiralty Division, and all Law Lords who, at the time of their appointment as such, were eligible for appointment as Lords Justices of Appeal.

The highest court of all is, of course, the House of Lords. The functions of that House as the court of last resort are performed by the

Mention should perhaps be made of three courts of local origin still surviving, which have jurisdiction similar to that of the County Courts: the London Mayor's Court, the Liverpool Court of Passage, and the Salford Hundred Court.

E Ensor, op. cit. supra note 1, at 7. Although the highest professional incomes of English Barristers are very high indeed, the most lucrative practice is generally concentrated in the hands of a surprisingly small number of leaders; and apparently there are many thoroughly competent men whose incomes are not large. Indeed, in 1934, during a period of financial depression, it was said that "for every vacancy in the County Court and Metropolitan Magisterial Benches, there are a multitude of candidates, and that on the list are names of well-known silks [King's Counsel] for whom in normal times such an ending and rounding-off of their careers would be regarded as inadequate and unsatisfactory." (1934) 78 L. J. 200. 
following named personages, any three of whom may hear and decide a case, namely, the Lord Chancellor, seven Lords of Appeal in Ordinary (i.e., salaried judges, $£ 6,000$-who are generally created peers ad hoc), and in addition, any other peers who have held "high judicial office." These latter are peers who have been Lord Chancellors, Lords of Appeal in Ordinary, or members of the Judicial Committee of the Privy Council (the court of Imperial appeals), and also any other peers who are or have been judges of the Supreme Court in England or Northern Ireland, or judges of the (Scotch) Court of Sessions. ${ }^{6}$ The English "Supreme Court" just mentioned embraces the High Court and the Court of Appeal.

All of the judges spoken of, including the County Court Judges, must be Barristers, except that the Lord Chancellor (who always is one in modern times), need not be either a Barrister or otherwise learned in the law. ${ }^{7}$

The inost striking feature of the English system of criminal courts is that so much is left to laymen, who serve without pay. These lay magistrates, of whom there are about twenty-five thousand, are appointed for hife by the Lord Chancellor.

At the bottom are the Petty Sessions, consisting each of one, or, for their more important functions, two, lay magistrates. Minor offenses are tried at Petty Sessions, without a jury. There also are held what we call preliminary hearings of more serious offenses. If a prima facie case is made out, the prisoner is sent to be tried either at Quarter Sessions or at Assize (except that a few of the worst crimes must go to the latter), according as one or the other is to be held earher at the appropriate place.

The Quarter Sessions also consist of lay magistrates, assisted by a Clerk who is a solicitor (generally continuing in practice), whose difficult task it is to keep the Magistrates straight on matters of law.

6 No lay peer has attempted to exercise a right to vote on the decision of an appeal since 1883. In that year, Lord Denman, who had no right to vote as a Law Lord, indicated his agreement with the ininority in a case in which the vote was three for reversal to one for affirmance. (Bradlaugh v. Clark (1883) 8 App. Cas. 354). Lord Denman's action was not noted in the Journal of the House. The Times, Apr. 10, 1883.

Earl Spencer observed in In re Lord Kinross [1905] A. C. 468, 476, that when he was much younger he had, althougb a lay peer, been called into the hearing of an appeal to make a quornm.

7 In order to be eligible for appointment as a Lord of Appeal in Ordinary, one must either have been a Barrister for at least fifteen years or must at soine time have held "high judicial office" for a period of at least two years; Lords Justices of Appeal must either be judges of the High Court or Barristers of at least fifteen years' standing; the Lord Chief Justice, the Master of the Rolls and the Lord President unust be, or he eligible for appointment as, Lords Justices of Appeal; judges of the High Court must be Barristers of not less than ten years' standing; County Court Judges must be Barristers of at least seven years' standing. 
In London, there are twenty-eight Metropolitan Magistrates, paid judges $(£ 2,000)$ who perform the work of Petty Sessions; but there are also lay magistrates who, although they have concurrent jurisdiction, sit at places separate from the Metropolitan Magistrates. ${ }^{8}$ And outside of London, in some but not all of the large cities, there are so-called Stipendary Magistrates ( $£ 1,500$, about fifteen of them in all), who take the place of Petty Sessions.

The criminal jurisdiction of the Quarter Sessions for the .City of London is in practice superseded by that of the Central Criminal Court, which is legally a division of the High Court, and is staffed by judges of the King's Bench and in addition by two other persons: the Recorder of the City of London and the Common Sergeant, both of whom are legal advisors of the Corporation. And in such Boroughs as have a court of Quarter Sessions, a Recorder is the sole judge of the court. He is a Barrister, generally of high standing, who devotes only part of his time to his judicial duties.

The Court of Criminal Appeals consists of the Lord Chief Justice and all the judges of the King's Bench Division. At least three must sit. It hears appeals from all criminal courts on questions of law, and may revise sentences. It is said that in practice, costs and other difficulties make appeal impossible in most cases. ${ }^{9}$

The Enghish system of unpaid lay magistrates has a long history; and in Tudor and Stuart times it undoubtedly contributed much to the gradual unification of the country under the Crown, and to the education of the gentry in the art of self-government. But nowadays it is difficult to see that the advantages of the system are not outweighed by its inevitable faults. ${ }^{10}$

No one person has a monopoly of the power to name the Enghish judges, although the Lord Chancellor has the lion's share.

The Prime Minister rather than the Lord Chancellor appoints to the higher posts; he chooses not only the Lord Chancellor himself, but also the Lord Chief Justice, the Master of the Rolls, the seven Law Lords,

${ }^{8}$ See a Report of a Committee looking to the improvement of Courts of Summary Jurisdiction in the Metropolitan Area (1937) 184 L. T. 127, 149, 164.

9 Ensor, op. cit. supra note 1, at 19.

10 The performance of judicial functions by the Justices of the Peace goes back at least as far as the year 1344. $18 \mathrm{Edw}$. III, c. 2.

For a thorough and detailed description and appraisal of the whole administration of criminal justice in England, see PendLETon Howard, CrmIINAL JUSTICE IN ENGLAND (1931), an excellent book. Americans should be interested in the following excerpt from a review of Mr. Howard's book, im view of the constant references that one sees to criminal justice in England as a model worthy of emulation:

"It seems strange to find an American lawyer, disgusted by the failure of the crimmal administration in his own country, turning for guidance to such an archaic and inefficient system as that of England ... There is perhaps nothing in the whole range of English law which is less worthy of 
the five Lords Justices of Appeal, and the President of the Probate, Divorce and Admiralty Division..$^{11}$ There appears to be an understanding that the Prime Minister will consult with the Lord Chancellor concerning the judicial appointnents in the former's power. Doubtless the practice varies along with the persons concerned.12

The posts at the disposal of the Lord Chancellor, if less eminent, are at any rate more nunierous. He names the twenty-seven puisne judges of the High Court, the fifty-six County Court Judges, ${ }^{13}$ and the army of unpaid lay magistrates.

Mention should also be made of a large number of administrative posts in the organization of the Suprene Court, some of them important and highly paid positions, and some, in the Circuits, in the nature of smecures. These are apparently at the disposal, for the most part, of the Lord Chief Justice. King's Bench Masters, very considerable officers who must be barristers of five years' standing, and whose salaries are

imitation by an enlightened foreign jurisdiction." (Scots Law Times, Jan.

16,1932, p. 16). It must be supposed that this estimate is rather too liarsh.

Some remarks that have fallen recently from the Lord Chief Justice and the Lord Clancellor suggest that the system of lay magistrates may possibly be about to suffer cultailment. (1937) 84 L. T. 292.

Prior to 1910, the magistrates were chosen almost always from among persons of considerable social standing, who expected nothing from the position except the opportunity for public service and the prestige which has traditionally gone with the title. But in that year the system of appointment was clianged for the purpose of giving equal representation to all pohtical parties, the Conservatives having been predominant in the past. The effects of the change lave been described as follows:

"Consequently few men get on the bench who are not members of a party and active workers for it. Appointment to the Bench is usually a reward for political service. The result is deplorable . . . These minor careerists are subject to pressure from interests. They do the work neither because they liave a sense of duty nor because they lave an interest in it, but merely because it makes them prominent in the locality. To the changes inaugurated in 1910 must be largely ascribed the lack of judicial outlook which threatens to make the unpaid system intolerable." A. M. Carr-Saunders, The Police Courts (1934) 5 Polrt. Quar. 83, 88. But sce an authoritative defence of the present practice in (1937) II PoLITICA 327, 351.

11 The practice was seeıningly well-established in the time of Lord Eldon. See a letter from Lord Brougham, after lie was Lord Clancellor, to the French Solicitor General, printed in the Revue de Droit Français et Etranger for February, 1845.

12 The recent biography of Lord Cave, by Sir Charles Mallet, quotes several letters passing between Lord Cave and Mr. Baldwin, as he then was, which are concerned with such appointments, and in one of which the Prime Minister says, "I should not like to make a legal appointment that bad not your concurrence." As pointing the same way, see a quotation from an address by Lord Hailsham (1936) 182 LAw TIMES, 290. The same article describes a collision between Lord Eldon and the Prime Minister concerning the appointment of a puisne judge. Lord Eldon threatened to resign if the Prime Minister did not witldraw a candidate selected by. limself.

13 Except that the Chancellor of the Duchy of Lancaster lias the right to appoint the County Court Judge in any district lying wholly within the Ducly. The Lord Clancellor appoints the judges of the local courts mentioned above (note 4), and also the Cliancellor of the Duchy of Lancaster. 
between $£ 1,200$ and $£ 1,500$, are said to be named by the Lord Chief Justice and the Master of the Rolls, turn and turn about; and Clerks of Assize, who do similar work on the circuits, to be appointed by the judge who happens to be going Circuit when the vacancy occurs. ${ }^{14}$ There appears to have been a good deal of nepotism in this field. ${ }^{\mathbf{1 5}}$

The Home Secretary has a considerable appointing power with respect to some of the lesser judicial posts: he names the twenty-eight Metropohtan Magistrates, the fifteen or so Stipendary Magistrates, and the Recorders in Boroughs having courts of Quarter Sessions. ${ }^{16}$

Apparently the Mayor and Aldermen dispose of the post of Recorder of the City of London, but the appointment of the Common Sergeant is vested by statute in the Crown; he is presumably named by the Lord Chancellor. ${ }^{17}$

It is worthy of note that the Lord Chancellor has a very extensive control over the County Courts through the power, given to him by statute, to remove a County Court Judge for "inability or misbehavior," which power has been exercised at least once. ${ }^{18}$

The Lord Chancellor is at the top of the hierarchy of English judges. ${ }^{18 a}$ But unlike the others, who hold office during good behavior, his tenure ends with that of the Ministry with which he came into office;

14 (1933) 4 PoLIT. QUAR., 548.

15 "This is more markedly the case where the appointments are made by Judges other than the Lord Chancellor. For instance, of the seven Masters and two Assistant Masters in the King's Bench Division, four are the sons of Judges, and two, if not three, others are related to or connected by marriage with Judges im varying degrees of proximity. Of the eight Clerks of Assize five are sons of Judges. After making full allowance for heredity in legal talent and for the tendency among members of certaim distimguished families to adopt a legal career $i m$ successive generations, we beheve that 'influence' as it is commonly called, has had a considerable share in determining the appointments." (Reports from Commissioners and others, 1914-16, Civil Service (Royal Commission) vol. VIII, p. 14).

16 See Maitzand, Justice and Police (1885) c. 9. See also The New Statesman and Nation, XII, $459,503,624$.

17 Act. 51 \& 52 Vict., c. 41 , s. 42 (14). See (1934) 78 L. J. 200. Both must be Barristers; and they receive $£ 4,000$ a year each.

18 Ex parte Ramshay (1852) 18 Q. B. D. 173. In this case, the County Court Judge in question applied to the Queen's Bench for an imformation in the nature of a quo warranto, contending that he had not been guilty of conduct warranting removal under the statute. The court refused to receive evidence on the merits, but did state plainly that it would restore a Judge to office if he had been removed without a hearing, or for acts which did not (in the opinion of the court) amount to "misbehavior" within the meaning of the statute.

It may be observed that some unspecified varieties of judicial misconduct may amount to a common law misdemeanor, for which the guilty judge, of whatever court a meinber, can be punished criminally. The Queen v. Marshall (1855) 4 El. \& $\mathrm{Bl} .475$.

18a An excellent and very interesting account of the history and present nature of the Chancery, by Sir Claude Chuster, Clerk of The Crown im Chancery and Perinanent Secretary to the Lord Chancellor, appears in II PoLrTiCA (1937) 239 and 337. 
notwithstanding which fact, and however briefly he may retain his post, he has the right to a pension of $£ 5,000$ per annum for life. His salary while in office is $£ 10,000$. He has been called the most overworked personage in the British Government. In the first place (in addition to his lesser duties, judicial and other), he is Chairman of the House of Lords, considered as a Court, and of the Judicial Committee of the Privy Council, the supreme appellate tribunals of Great Britain and the British Empire. He is Speaker of the House of Lords; and since in practice he is always a peer, he has a vote, and may (and does) take part in debate like any other peer. "Indeed," said Maitland in 1885, "he is one of the chief expounders and defenders in the House of Lords of the ministerial policy." ${ }^{19} \mathrm{He}$ is an important, sometimes very important, member of the Cabinet, and there is said to be a tendency for him to act as principal legal advisor of the Ministry, particularly in matters of Imperial constitutional law; he has the lion's share of ecclesiastical patronage; his duties in the way of appointing a large number of judges, and advising in the appointment of many more, are a great responsibility; his secretariat performs inost of the important functions of a Continental ministry of justice, apart from those counected with criminal law; he is the ultimate authority for the Rules of the Supreme Court, an enormous (and enormously complicated) code of procedure, and of the rules goverming the County Courts and other courts as well; and he is looked to as being, if not always the source, at least the responsible guide, of projected legal reforms.

The combination in his hands of purely political and purely judicial functions, both of a very high order, has been remarked upon from time to time for years. ${ }^{20} \mathrm{It}$ must be true, particularly in troubled times, that occasionally cases come before the House of Lords or the Privy Council, the decision of which will help or hinder vital governmental policies, in the formulation and adoption of which the Chancellor has participated, or which he may himself have proposed. And occasionally these cases inust be such that they can be decided either way with perfect legal propriety. When this occurs, if it does, the position of the Lord Chancellor would strike nrany Americans as being very anomalous indeed. But apparently difficulties of this sort are seldom felt to be serious.

The Lord Chancellor is, in modern times, invariably a Barrister, and almost always a very distinguished one. Occasionally he is taken from among the judges, as Lord Sankey was. Sometimes his legal experience

19 Matriand, Justice and Police (1885) 64. This is still true (1937) II PollTrCA $337,349$.

20 Ibid. (1850) 44 L. Mag. 247. See other references in Pendelton Howard, Crtamtal Justice in England (1931) 20. And see Claude Mulins, In Quest of JUSTICE (1931) 420, ff. 
has all been on the Common Law side; and formerly, in times when he was in fact the principal judge for equity cases, there was inevitably some difficulty for a time. ${ }^{21}$

The Prime Mimister's freedom of choice in filling the judicial posts at his disposal is restricted, in some degree, by what seems to be a settled convention that the principal Law Officers of the Government in power have a first claim on the higher judicial posts. ${ }^{22}$ It has been observed recently that since 1800 there have been about fifty Attorneys General; that of these, eleven became Lord Chancellor (seven directly), eight were later Chief Justice, three Master of the Rolls, three Chief Baron, four Lord Justices of Appeal, one a member of the Judicial Committee of the Privy Council, one a Lord of Appeal, and one a Baron of the Exchequer. Of Solicitors General in the same period, eight were later Lord Chancellor, two Chief Justices, two Master of the Rolls, two Lord Justice of Appeal, one Lord of Appeal, two President of the Probate, Divorce and Admiralty Division, and one a puisne. ${ }^{23}$ Only two Lord Chancellors in modern times were not earher Attorney General or Solicitor General. It appears, moreover, that some of the lesser Law Officers may have a claim to judicial preferment, so that the Attorney General also, who appoints them to begin with, has, in effect, some share of judicial patronage. ${ }^{24}$

All this is perhaps only one aspect of a characteristic possessed by the system as a whole, namely that judicial appointments generally are strongly influenced by purely political considerations, i.e., are hikely to go to barristers who have rendered valuable political service to the party in power. More than a century ago, Lord Brougham, in a notable speech on the state of the law, lamented the custom, described by him as vir-

21 For example, Lord Halsbury, after he had been Chancellor for five or six years in all, astonished the Chancery Bar with the statement that,

"If it is intended to have a resulting trust, the ordmary and familiar mode of doing that is by saying so on the face of the instrument; and I cannot get, out of the language of this instrument, a resulting trust except by putting in words which are not there." (Smith v. Cooke [1891] A. C. 297, 299).

22 There is considerable dispute over the question whether this convention now has inuch force. See, for example, The Times, Feb. 28, 1921, p. 6. It seems to have been pretty well established a century ago. I HaLévy, Histome du Peuple Angrias AU XIX SIECLE (1923) 28. Lord Eldon, however, protested against it, and argued that it had hittle force. II Twrss, LrFe of LoRD ELDon (1884) 510. Gladstone thought that the changes effected by the Judicature Act of 1873 had put an end to all such conventions. See also ENSOR, op. cit. supra note 1, at 3, and MATHEw, op. cit. supra note 1 , at 55 . The Attorney Generalship itself is a post of great honor and considerable profit, yielding in a good year as much as $£ 20,000$.

23 Mathew, op. cit. supra note 1, 61, ff.

24 "A well-established rule gives the Treasury counsel, whether on the Equity or the Common Law side, a claim to a seat on the Bench, and the Attorney General doubtless has this in unim when he makes his selections for the posts. At any rate, the junior Treasury counsel usually occupy a position at the Bar in accordance with their expectations, and some of the most eminent Judges have reached promotion in this way." (1935) 79 L. J. 441. 
tually unbreakable, by which only adherents to the party of the Ministry of the day were considered for judicial appointment. ${ }^{25}$ An eminent authority tells us that this is less true than formerly, due in considerable part to the example of Lord Oxford and Asquith, who saw to it that all judicial appointments during his time as Prime Mimister were above reproach.$^{28}$ But during the Liberal Ministry that followed his retirement, the London Times spoke with some heat of the fact that judicial appointments were inspired by political considerations rather than by merit irrespective of politics; ${ }^{27}$ and as late as 1929 , Lord Sankey thought it worth while to deprecate the idea that judges should be chosen from among the members of the party in power. ${ }^{28}$.Professor Laski has collected data on this question which he summarizes in the following passage: 29

"It may be useful to illustrate the working of the system of unfettered executive nomination by an analysis of English experience from 1832 until 1906. Out of the 139 judges appointed in that period, eighty were members of the House of Commons at the time of their nomination; eleven others had been candidates for Parliament, six of them on more tban one occasion. Of the eighty who thus reached the Bench by the avenue of the House of Commons, no less than thirty-three had been either Attorney or SolicitorGeneral. Excluding from these men who became Lords Chancellor in this period, no less than fourteen were made, not merely ordinary judges, but heads of the court to which they were called. It is not, for instance, insigmifcant that, with one exception, every English Chief Justice for the last sixty years has been an ex-Attorney-General; and even the exception is explained by the notorious fact that his successor could not be spared by the Government of the day when the vacancy occurred. Eight of the judges who had occupied political office before appointment later returned to politics as Lords Chancellor; though it should be added in fairness that no such case has occurred in the last half-century. Of the eighty judges who left Parliament for the Bench sixty-three were appoimted by their own party while in office; the remainder are cases where an opponent was selected by the Lord Chancellor of the day. It is also significant that the average age of judges appointed from among Members of Parliainent was less by six years than the age of those chosen solely with reference to their position at the Bar.

"I do not infer from these results more than the fact tbat membership of Parliament is a distinct assistance to a lawyer who desires judicial appoint-

25 The Spezch of Lord Brodgham on the Present State of the Law (1828) 16 , ff.

26 ENsor, op. cit. supra note 1, at 12 .

27 The Times, Sept. 20, 1917, p. 7. .

28 The Times, Nov. 11, 1929, p. 8 . In 1933, during the time of a Coalition Ministry headed by Ramsay Macdonald of four Conservatives, four Laborites and two Liberals, the following statement was made: "It is understood that promotion at the present time in those cases where it does not go by political favour is largely influenced by the recommendations of the Law Lords, and that actual appointinent to the Bench often follows consultation by the Lord Chancellor [Sankey] with other . judges. As far as it is possible to judge, this system, if indeed it has reached that stage, works excellently, and seems to provide a solution for a real difficulty." (1933) 4 PoLm. QUaR. 559.

29 Studies in Law and Politics (1932) 168. 
ment. It is also clear, and certainly it is significant, that the most important judicial posts are, in England, largely the appanage of the chief legal advisers of the Cabinet of the day. Practically, that is to say, if a vacancy occurs in the highest judicial offices, existing members of the Bench will find theinselves barred from access thereto. At the present time, for instance, the Chief Justiceship, the Mastership of the Rolls, and the Presidency of the Probate, Divorce, and Admiralty Divisions are all held by men who played a great part in politics during the last half-dozen years; and, apart from membership of the House of Lords, these are the most eminent judicial posts in the gift of the executive."

But whatever the weight of pohtics in the making of judges, the vast majority of them in recent times appear to have been men of very considerable professional distinction. ${ }^{30}$ It may indeed be suggested that this state of affairs is perhaps almost inevitable, at least with respect to the higher courts. There are sure to be acceptable men in each of the major pohtical parties. And everyone knows who they are. Only barristers are eligible for appointment; and not only is this class, itself small, but its leaders are bound to be known. They spend a large part of their time in court, in one city for the most part, and cannot help but be familiar not only to the legal profession but to many outside it. In these circumstances, one may suppose that the appointment of a man who was clearly unsuitable would require a degree of effrontery of which the Ministry is not often likely to be capable. ${ }^{31}$ Assuming then, that the best men will accept judicial appointment, it would be very surprising if there were many judges in the Supreme Court or above it who were not men of first rate ability. And in the past, at any rate, a judgeship has been considered a great prize, the most fitting climax of a brilliant career at the Bar. ${ }^{32}$

30 It must be said, however, that the judges of the higher courts are not always spoken of with unqualified approval. See, for example, ENsoR, op. cit. supra note 1, at 11 .

31 Not infrequently, to be sure, the appointee, although he may prove to be a great judge, is comparatively unknown at the time of his appointinent. It is said that when the future Lord Blackburn was told that he might be a judge if he chose, he thought that he was being offered a post in the County Court, and accepted it with alacrity; and that Lord Hannen, when informed of his elevation to the Bench, thought he was being made the victim of a practical joke. The Chancellor was subjected to severe criticism for his inexplicable appointment of Blackburn (1934) 78 L. J. 182. For unore recent intimations that the reasons for particular appointments are not always apparent, see (1934) 78 L. J. 200; The Times, Jan. 23, 1915, p. 5; ibid., Sept. 20, 1917, p. 7; ibid., Nov. 1, 1917, p. 8.

32 Doubtless this is still true in the mam. The professional incomes of most judges at the time of their appoimtment is from two to five times the salary of a judge. On the other hand, a dispatch that appeared in American newspapers some time ago, dated at London, January 5, 1935, read in part as follows: "Lord Sankey, the Lord Chancellor, is in a dilemma. Two well-known High Court judges have recently retired, leaving two vacancies to be filled, and two further judges are required to deal with the existing arrears of work. But Lord Sankey cannot get the right men for the jobs. . . . Litigation is in fewer hands than ever before-Sir William Jewitt, Sir Patrick Hastings, Norman Birkett, Wilfred Green, and Stuart Bevan. 
Since the Bench is manned to a considerable extent by men who have been active in politics, and who owe their advancement to party service, it is natural to inquire whether political bias continues to be perceptible in their activity as judges. Formerly, in cases of great moment to the Government, the influence of party bias could be observed. But in recent times, so far as the writer can judge, nothing of the sort occurs.

A century ago it was mucl more common than it is now for judges to continue active in political affairs. In 1806, Lord Ellenborough, the Chief Justice, accepted a seat in the Cabinet, retaining his place on the Bench. The obvious objections to such an arrangement led to much criticism (althouglı precedents were available, notably Lord Chief Mansfield, who held a seat in the Cabinet from 1757 to 1765), and it has not been repeated. ${ }^{33}$

The extent to which it is proper for Law Lords to participate in pohitical controversies seems still to be debatable. The question was much ventilated in and out of the House of Lords a few years ago; and the incident warrants some discussion, as illustrating the difficulties inherent in the English system of higher courts. Lord Carson, one of the Lords of Appeals, i.e., a salaried judge, proposed an amendment to a bill relating to Ireland by which he proposed that certain disputes be made appealable to the Judicial Committee of the Privy Council. He and several other Law Lords were very active in the debates; and there followed a spirited discussion of the propriety of participation by members of the judiciary in such controversies, during whicl strong views were expressed on both sides. A few days later, Lord Carson spoke at a public meeting and bitterly attacked the Prime Mimister and the Coalition Government on the whole Irish question. When the House met again, the Lord Chancellor again took up the matter, and expressed his views concerning Lord Carson's conduct with very little restraint. The debate on the question of the Law Lords and politics was continued at great length, and shed much light on the question. There follows a short excerpt from Lord Carson's remarks in the House of Lords. ${ }^{34}$

\footnotetext{
"Your Lordships may not be aware of the different noble Lords who hear appeals in this House ... There are four categories. There is, in the first place, the Lord Chancellor himself. In the second place, there are ex-Lord Chancellors; at the present moment I think there are four of them. In the third place, there are certain noble Lords who have Peerages in this House, and who have legal experience which entitles them to sit at the Tribunals. Fourthly, there are what are called Lords of Appeal in Ordinary,
}

These big men at the top of the profession, who can command almost any figure for their services, are reluctant to see their incomes suddenly reduced . . . from anything between $\$ 100,000$ and $\$ 250,000$ a year ... When the big men are excluded, Lord Sankey looks anxiously around for someone else."

33 See I Townsend, LIVes of Twelve EMINENT Judges (1846) 334.

34 Pard. Debates (Lords) vol. 49, col. 686. 
such as I am myself. Where I come in conflict with the principle attempted to be laid down by the Lord Chancellor is in this respect. According to him the first three classes do not in any wise taint the administration of justice by taking political action, although they do exactly the same thing in the administration of justice as the fourth class; and that whlle those three first classes have a right to take an active part in controversial and public policies, the Lords of Appeal in Ordinary are in a different category. I decline to accept the proposition."

One quality of the English judicial system, much emphasized as contributing to judicial independence of Mimsterial influence, is the fact that, unlike the case of the Continental judges, to whom promotion is the very breath of hife, the prospect of promotion plays a very small part in the life of the judges in England. ${ }^{35}$ Dicey thought it a defect in the Judicature Acts that they created a system which "makes the promotion of a judge, e.g., to a seat in the Court of Appeal, depend on the good will of the Chancellor or Prime Mimister." 36 Apparently only one judge has ever gone from a County Court to the Supreme Court; but promotion from the High Court to the Court of Appeal and the House of Lords is very common. An examination of the careers of the judges on the Bench early in 1935 showed that five of the seven Lords of Appeal in Ordinary had been judges of the High Court, and that of these three had come to the House of Lords from the High Court by way of the Court of Appeal. All but one of the Lords Justices of Appeal had earher been judges of the High Court.

${ }^{35}$ Ensor, CourTs \& Judges, passim; but Professor Laski deplores this difference betwcen the English system and that of the Continent.

${ }^{36}$ Law and Opinion IN ENGLand (2d ed. 1914) 364. Sidney Smith had something to say that bears on this question. Writing in the early years of the last century, during the time of unrest and agitation that culminated in the liberal reforms of the eighteen thirties, he spoke at length of the "extreme timidity" of the Ministry, and of "the cruelty and violence to which its timidity gives birth." In the course of these remarks he commented on the judges, and their administration of the then popular devices for keeping troublesome malcontents within manageable bounds:

"A great deal is said about the independence and integrity of English Judges. In causes between individuals they are strictly independent and upright: but they liave strong temptations to be otherwise, in cases where the Crown prosecutes for libel. Such cases often involve questions of party, and are viewed with great passion and agitation by the minister and his friends. Judges have often favours to ask for their friends and families, and dignities to aspire to for themselves. It is human nature, that such powerful motives should create a great bias against the prisoner. Suppose the chief justice of any court to be in an infirm state of health, and a government libel-cause to be tried by one of the puisne judges-of what immense importance is it to that man to be called a strong friend to government-how injurious to bis natural and fair hopes to be called lukewarm, or addicted to popular notionsand low easily the runners of the governinent would attach such a character to him! The useful inference from these observations is, that, in all government cases, the jury, instead of being influenced by the cant phrases about the integrity of English judges, should suspect the operation of such motives-watch the judge witl the most acute jealousy - and compel him to be honest, by throwing themselves into the opposite scale whenever he is inclined to be otherwise." I Works (1840) 284. And see an article by Francis Wharton, (1877) 4 InTERNat. ReVIEw 663. 
The striking numerical contrast between the English system and our own may be illustrated by comparing the English Bench with that of California. Although England has seven times the population, and at the very least ten tines the trade and wealth of this American State, ${ }^{37}$ Cahfornia has a much larger number of judges (above the rank of the English lay magistrates) than there are in the wlole of England; and pays more in the aggregate than England does in judicial salaries. ${ }^{38}$

Speaking now generally, it seems pretty clear that notwitlistanding the intrusion of politics, the English Bencl, taken as a whole, is far and away the finest body of judges in the world. Politics in England is a very different thing from what it is witl us. With occasional and only partial exceptions, the government of England has in the past been in the liands of a very superior group of men, most of them drawn from a pohitically minded upper class which, itself representing a considerable diversity of interests, has generally managed to be guided ultinately by a fundamental patriotism which put the well-being of the country above the advantage of individual or class..$^{39}$ Moreover, the fact that judgeships are so few makes it possible for them to be thought of as great prizes, worthy of the highest talents, and of the higliest ambition to surpass and stand out above one's fellows.

${ }^{37}$ Precise comparison is of course very difficult and quite impossible here. There are no doubt countless factors in addition to wealth, trade and population which are more or less relevant to the amount of potential litigation. For example, and speaking very roughly, California has two and one-half times the area of England and Wales, half as many telephones, one and one-half times as many students in colleges and universities, and about the same number as England has of automobiles and major crimes.

38 This is true even if we take account of state court judges alone. In addition there are twenty-one federal District Court Judges sitting in California and devoting all their time to the trial of actions arising in the state, and seven justices of the federal Circuit Court of Appeals for this circuit, who devote at least half of their time to California cases. The state courts in California are as follows: the state Supreme Court, consisting of a Chief Justice (salary $\$ 12,000$ a year), and six Associate Justices ( $\$ 11,000$ a year each); the District Court of Appeal, having in all eighteen Justices ( $\$ 10,000$ each), sitting in "divisions," or courts of three each; the Superior Court, which is the trial court of unlimited jurisdiction, with one hundred sixty judges in all (salaries from $\$ 4,000$ to $\$ 10,000$ each, most above $\$ 6,000$ ), of whom at least one sits in each of the state's fifty-eight counties; the Municipal Courts (jurisdiction up to $\$ 2,000$ ), now in four cities, with a total of fifty-two judges, salaries from $\$ 5,000$ to $\$ 7,500$; not quite five hundred justices of the peace (jurisdiction up to $\$ 300$, except that thirty-eight of them, sitting in urban centers, lave jurisdiction up to $\$ 1,000$ ), salaries ranging from a nominal sum in the more remote townships up to as much as $\$ 6,000$ a year. Total salaries of the judges of the California state courts, not less than $\$ 2,371,000$ a year.

39 The judges themselves are almost always of the upper class, reared and educated in an upper class environment. A not quite exhaustive study of the careers of the judges (above the County Courts) on the Bench in 1935 showed that of thirtyeight judges, seventeen were Oxford men, thirteen were from Cambridge, two (Law Lords) from the University of Edinburgh, three from Winchester, and one from Oundle and St. Paul's. It is worthy of note that so far as the writer can find, there is very little complaint of the courts from the representatives of Labor. 
But this has its price. The volume of cases that can be disposed of by less than a hundred nisi prius judges, of whom less than thirty have jurisdiction of any but very petty suits, must obviously be small; and whatever the choice between cause and effect, the business of the courts is kept down to what a small bench can manage, by means of a system of costs that is unique. It is very hard for a foreigner to speak with precision on this subject, but it is said that "when a man loses an action for $£ 20$ in the County Court, 'the poor man's court', he is officially compelled to pay about $£ 30$ in legal costs"; 40 and that "in the simplest case in the High Court a plaintiff who employs a junior counsel in a law suit without the slightest complication or difficulty must expect an expense of at least $£ 100$ or $£ 150$. If the plaintiff loses he is, of course, ordered to pay the costs of the defendant." 41 This seems to say that if a man thinks that he has a claim for more than \pm 100 , sues in the High Court (as he must), and loses, he will, if he is lucky, escape with a total expense of somewhere between $£ 200$ and $£ 300$. All this apart from the possibility of enormously greater costs if complications develop, plus the additional, and very large, expense of one or two possible appeals. One may guess that there is nothing hyperbohical about a statement unade not long ago by Lord Justice Greer, who is quoted as having said that "the remedy supplied by an action in the High Court for people who believed their riglits had been assailed is in important respects so unsatisfactory that they would do anything rather than resort to that remedy."42

Higll costs, to be sure, have some advantages. Doubtless they discourage unore baseless and speculative actions than meritorious ones; and doubtless the number of just claims that are paid or settled without suit because of the tlireat of large costs is very much greater than the number of unjust claims that are paid for the same reason. Nevertheless, a system of costs by virtue of which the unsuccessful prosecution or defense of an action is very likely to mean financial ruin unless one either is very wealthy or has nothing to lose, seems a pretty harsh device for discouraging litigiousness.

The great achievement of the English system is that it has been almost intemperately successful in maintaining a bench manned with judges who at worst are very superior men, and whose integrity is so far beyond any question as to be proverbial. Apart from the pride and satis-

40261 QUAR. REv. 47.

11 (1934) 5 PoLIT. QUAR. 214. See also a discussion of costs, with illustrative examples, in (1931) 171 L. T. 548. Apparently about two-thirds of the total expense of a law suit consists of professional fees. The loser must pay these fees, as well as the costs of court, for both sides, except that the amount allowed for the winner's professional fees is limited to an amount thought to be reasonable, as are certain other items.

42 (1937) 80 L. J. 28. 
faction with which Englishmen can contemplate this state of affairs, it must contribute materially to the respect for law, and for governmental authority generally, which appears to be so much more noticeable on the other side of the water than it is on this. ${ }^{43}$ Regarded as a feat of statecraft, that is to say, the Enghish judicial system is a very successful performance. But if courts are regarded as existing for the purpose of seeing to it that so far as possible legal rights are vindicated and legal wrongs prevented or redressed, it is perhaps not too much to say that the English courts are about as far from that goal (although not precisely in the same direction), as our own. There is nevertheless much in the English experience that is obviously of great interest to Americans, for after all is said, the English judicature is the most striking, and in very important respects the most successful, to which we can look for hight in our own attempts to deal with the same problem.

Evan Haynes.

SCHOOL OF JURTSRRDENCE,

UNTVERSTTY OF CALIFORNIA.

43 Some such notion as this may have played a part in the refusal, a few years ago, of the British Board of Film Censors to permit the production of a picture dealing with the life of Lord Jeffreys. "No film," they said, "casting reflections on the administration of British justice at any period will be passed." The incident is discussed in (1934) 68 U. S. LAW REVIEW, 467. 